\title{
Environmental Policy and Technological Change
}

\author{
ADAM B. JAFFE ${ }^{1}$, RICHARD G. NEWELL ${ }^{2}$ and ROBERT N. STAVINS ${ }^{3 *}$ \\ ${ }^{1}$ Department of Economics, Brandeis University and National Bureau of Economic Research; \\ ${ }^{2}$ Resources for the Future; ${ }^{3}$ John F. Kennedy School of Government, Harvard University and \\ Resources for the Future (*author for correspondence, e-mail: robert_stavins@harvard.edu)
}

\begin{abstract}
The relationship between technological change and environmental policy has received increasing attention from scholars and policy makers alike over the past ten years. This is partly because the environmental impacts of social activity are significantly affected by technological change, and partly because environmental policy interventions themselves create new constraints and incentives that affect the process of technological developments. Our central purpose in this article is to provide environmental economists with a useful guide to research on technological change and the analytical tools that can be used to explore further the interaction between technology and the environment. In Part 1 of the article, we provide an overview of analytical frameworks for investigating the economics of technological change, highlighting key issues for the researcher. In Part 2, we turn our attention to theoretical analysis of the effects of environmental policy on technological change, and in Part 3, we focus on issues related to the empirical analysis of technology innovation and diffusion. Finally, we conclude in Part 4 with some additional suggestions for research.
\end{abstract}

Key words: diffusion, environmental policy, innovation, invention, technological change

\section{Economic Frameworks and Issues in Technological Change}

Economists have examined a diverse set of issues associated with technological change that go well beyond those analyses that have focused directly on implications for environmental policy, including: the theory of incentives for research and development (Tirole 1988; Reinganum 1989; Geroski 1995); the measurement of innovative inputs and outputs (Griliches 1984 and Griliches 1998); analysis and measurement of externalities resulting from the research process (Griliches 1992; Jaffe 1998); the measurement and analysis of productivity growth (Jorgenson 1990; Griliches 1998; Jorgenson and Stiroh 2000); diffusion of new technology (Karshenas and Stoneman 1995; Geroski 2000); the effect of market structure on innovation (Scherer 1986; Sutton 1998); market failures related to innovation and appropriate policy responses (Martin and Scott 2000); the economic effects of publicly funded research (David et al. 2000); the economic effects of the patent system (Jaffe 2000); and the role of technological change in endogenous macroeconomic growth (Romer 1994; Grossman and Helpman 1994). In this part of the article, we provide a very brief guide to some of this research. In particular, we introduce approaches for measuring technological change, we examine critical aspects of the process of technological change, and we describe modeling 
approaches and potential market failures relating to technology innovation and diffusion.

\subsection{MEASUREMENT OF TECHNOLOGICAL CHANGE}

The measurement of the rate and direction of technological change rests fundamentally on the concept of the transformation function,

$$
T(Y, I, t) \leq 0
$$

where $Y$ represents a vector of outputs, $I$ represents a vector of inputs, and $t$ is time. Equation (1) describes a production possibility frontier, that is, a set of combinations of inputs and outputs that are technically feasible at a point in time. Technological change is represented by movement of this frontier that makes it possible over time to use given input vectors to produce output vectors that were not previously feasible.

In most applications, separability and aggregation assumptions are made that make it possible to represent the economy's production technology with a production function,

$$
Y=f(K, L, E ; t),
$$

where $Y$ is now a scalar measure of aggregate output (for example, gross domestic product), and the list of inputs on the right-hand side of the production function can be made arbitrarily long. For illustrative purposes, we conceive of output as being made from a single composite of capital goods, $K$, a single composite of labor inputs, $L$, and a single composite of environmental inputs, $E$ (for example, waste assimilation). Again, technological change means that the relationship between these inputs and possible output levels changes over time.

Logarithmic differentiation of the production function (Equation (2)) with respect to time yields

$$
y_{t}=A_{t}+\beta_{L t} l_{t}+\beta_{K t} k_{t}+\beta_{E t} e_{t},
$$

in which lower case letters represent the percentage growth rates of the corresponding upper case variable; the $\beta$ 's represent the corresponding logarithmic partial derivatives from Equation (2); and the $t$ indicate that all quantities and parameters may change over time. ${ }^{1}$ The term $A_{t}$ corresponds to "neutral" technological change, in the sense that it represents the rate of growth of output if the growth rates of all inputs were zero. But the possibility that the $\beta$ 's can change over time allows for "biased" technological change, that is, changes over time in relative productivity of the various inputs.

Equations (2) and (3) are most easily interpreted in the case of process innovation, in which firms figure out more efficient ways to make existing products, allowing output to grow at a rate faster than inputs are growing. In principle, 
these equations also apply to product innovation. $Y$ is a composite or aggregate output measure, in which the distinct outputs of the economy are each weighted by their relative value, as measured by their market price. Improved products will typically sell at a price premium, relative to lower quality products, meaning that their introduction will increase measured output even if the physical quantity of the new goods does not exceed the physical quantity of the old goods they replaced. In practice, however, product improvement will be included in measured productivity only to the extent that the price indices used to convert nominal GDP or other nominal output measures to real output measures are purged of the effects of product innovation. In general, official price indices and the corresponding real output measures achieve this objective only to a limited extent.

On its face, Equation (3) says nothing about the source of the productivity improvement associated with the neutral technological change term, $A_{t}$. If, however, all inputs and outputs are properly measured, and inputs (including R\&D) yield only normal investment returns, then all endogenous contributions to output should be captured by returns to inputs, and there should be no "residual" difference between the weighted growth rates of inputs and the growth rate of output. The observation that the residual has been typically positive is therefore interpreted as evidence of exogenous technological change.

\subsection{PROCESS OF TECHNOLOGICAL CHANGE}

Economic theories of the process of technological change can be traced to the ideas of Josef Schumpeter (1942), who distinguished three stages in the process by which a new, superior technology permeates the marketplace. Invention constitutes the first development of a scientifically or technically new product or process. Inventions may be patented, though many are not. Either way, most inventions never actually develop into an innovation, which is accomplished only when the new product or process is commercialized, that is, made available on the market. A firm can innovate without ever inventing, if it identifies a previously existing technical idea that was never commercialized, and brings a product or process based on that idea to market. The invention and innovation stages are carried out primarily in private firms through a process that is broadly characterized as "research and development" (R\&D). ${ }^{2}$ Finally, a successful innovation gradually comes to be widely available for use in relevant applications through adoption by firms or individuals, a process labeled diffusion. The cumulative economic or environmental impact of new technology results from all three of these stages, ${ }^{3}$ which we refer to collectively as the process of technological change.

\subsection{INDUCED INNOVATION AND EVOLUTIONARY APPROACHES}

If the imposition of environmental requirements can stimulate invention and innovation that reduces the cost of complying with those requirements, this has profound 
implications for both the setting of environmental policy goals and the choice of policy instruments. It is useful to identify two major strands of thought regarding the determinants of innovative activity. We call these two broad categories of modeling approaches the "induced innovation" approach and the "evolutionary" approach.

Induced innovation. Within the induced innovation approach, firms undertake an investment activity called "R\&D" with the intention of producing profitable new products and processes. Decisions regarding the magnitude and nature of $R \& D$ activities are governed by firms' efforts to maximize their value, or, equivalently, to maximize the expected discounted present value of cash flows. In some applications, the output of R\&D is explicitly modeled as "knowledge capital," an intangible asset that firms use together with other assets and other inputs to generate revenues (Griliches 1979; Hall et al. 2000).

When viewed as an investment activity, R\&D has important characteristics that distinguish it from investment in equipment or other tangible assets. First, although the outcome of any investment is uncertain to some extent, $R \& D$ investment appears to be qualitatively different. Not only is the variance of the distribution of expected returns much larger than for other investments, but much or even most of the value may be associated with very low-probability but very high value outcomes (Scherer et al. 2000). This skewness in the distribution of the outcomes of the research process has important implications for modeling firms' R\&D decision making (Scherer and Harhoff 2000). In addition, the asset produced by the R\&D investment process is specialized, sunk and intangible, so that it cannot be mortgaged or used as collateral. The combination of great uncertainty and intangible outcomes makes financing of research through capital market mechanisms much more difficult than for traditional investment. The difficulty of securing financing for research from outside sources may lead to under-investment in research, particularly for small firms that have less internally generated cash and/or less access to financial markets.

In addition to these financing difficulties, research investment differs from physical investment because the asset produced by the research process - new knowledge about how to make and do things - is difficult to exclude others from using. As first noted in the classic paper by Arrow (1962), this means that the creator of this asset will typically fail to appropriate all or perhaps most of the social returns it generates. Much of this social return will accrue as "spillovers" to competing firms, to downstream firms that purchase the innovator's products, or to consumers (Griliches 1979, 1992; Jaffe 1986, 1998). This "appropriability problem" is likely to lead to significant underinvestment by private firms in $R \& D$, relative to the social optimum (Spence 1984).

The recognition that $R \& D$ is a profit-motivated investment activity also leads to the hypothesis that the rate and direction of innovation are likely to respond to changes in relative prices. Since environmental policy implicitly or explicitly 
makes environmental inputs more expensive, the "induced innovation" hypothesis suggests an important pathway for the interaction of environmental policy and technology, and for the introduction of impacts on technological change as a criterion for evaluation of different policy instruments. We consider empirical approaches and evidence on induced innovation in Section 3.1 below.

The evolutionary perspective. While viewing $\mathrm{R} \& \mathrm{D}$ as a profit-motivated investment activity comes naturally to most economists, the large uncertainties surrounding the outcomes of $R \& D$ investments make it very difficult for firms to make optimizing R\&D decisions. Accordingly, Nelson and Winter (1982) used Herbert Simon's idea of boundedly rational firms that engage in "satisficing" rather than optimizing behavior (Simon 1947) to build an alternative model of the R\&D process. In this "evolutionary" model, firms use "rules of thumb" and "routines" to determine how much to invest in $\mathrm{R} \& \mathrm{D}$, and how to search for new technologies. The empirical predictions of this model depend on the nature of the rules of thumb that firms actually use (Nelson and Winter 1982; Winter et al. 2000).

If firms are not optimizing, a logical consequence of the evolutionary model is that it cannot be presumed that the imposition of a new external constraint (for example, a new environmental rule) necessarily reduces profits. There is at least the theoretical possibility that the imposition of such a constraint could be an event that forces a satisficing firm to rethink its strategy, with the possible outcome being the discovery of a new way of operating that is actually more profitable for the firm. This raises the possibility that environmental regulation can lead to a "win-win" outcome in which pollution is reduced and profits increased.

Porter and other "win-win" theorists have argued that in a non-optimizing world, regulation may lead to "innovation offsets" that "can not only lower the net cost of meeting environmental regulations, but can even lead to absolute advantages over firms in foreign countries not subject to similar regulations" (Porter and van der Linde 1995: 98). Of course, the fact that firms engage in non-optimizing behavior creates a possibility for profit improvements, without suggesting that such improvements would be the norm, would be systematic, or even likely.

Porter and van der Linde (1995) provided case studies of firms which adopted new technology in response to regulation, and appear to have benefited, but win-win theorists do not claim that all environmental regulations generate significant innovation offsets. Indeed, they emphasize that regulation must be properly designed in order to maximize the chances for encouraging innovation. Quantitative evidence is limited - much of it from a large related literature on the impact of environmental regulation on productivity and investment ${ }^{4}$ - and results seem to be industry and methodology dependent.

Boyd and McClelland (1999) and Boyd and Pang (2000) employ data envelopment analysis to evaluate the potential at paper and glass plants for "win-win" improvements that increase productivity and reduce energy use or pollution. They suggest that the paper industry could reduce inputs and pollution by $2-8 \%$ without 
reducing productivity. Berman and Bui (2001) found significant productivity increases associated with air pollution regulation in the oil refining industry, but Gray and Shadbegian (1998) found that pollution abatement investment "crowds out" productive investment almost entirely in the pulp and paper industry. Greenstone (1998) found that air pollution regulation has a statistically significant but very small impact on overall costs, implying a small negative productivity impact.

Generally, economists have been skeptical of the win-win theory (Palmer et al. 1995; Oates et al. 1993). From a theoretical perspective, it is possible to model apparently inefficient firm behavior as the (second-best) efficient outcome of imperfect information and divergent incentives among managers or between owners and managers in a principal/agent framework. ${ }^{5}$ From this perspective, the apparent inefficiency does not have normative implications. Since firms are doing the best they can given their information environment, it is unlikely that the additional constraints represented by environmental policy interventions would be beneficial. On a more concrete level, Palmer et al. (1995) surveyed firms affected by regulation - including those cited by Porter and van der Linde as success stories - and found that most firms say that the net cost to them of regulation is, in fact, positive.

For regulation to have important informational effects, the government must have better information than firms have about the nature of environmental problems and their potential solutions. Furthermore, while it seems likely that environmental regulation will stimulate the innovation and diffusion of technologies that facilitate compliance, creation and adoption of new technology will typically require real resources, and have significant opportunity costs. Overall, the evidence on induced innovation and the win-win hypothesis seems to be a case of a "partially full glass" that analysts see as mostly full or mostly empty, depending on their perspective.

\subsection{MICROECONOMICS OF TECHNOLOGY DIFFUSION}

From the mechanical reaper of the nineteenth century (David 1966), through hybrid corn seed (Griliches 1957), steel furnaces (Oster 1982), optical scanners (Levin et al. 1987) and industrial robots (Mansfield 1989), research has consistently shown that the diffusion of new, economically superior technologies is a gradual process. Typically, the fraction of potential users that has adopted a new technology follows a sigmoid or "S-shaped" path over time, rising only slowly at first, then entering a period of very rapid growth, followed by a slowdown in growth as the technology reaches maturity and most potential adopters have switched (Geroski 2000).

The explanation for the apparent slowness of the technology diffusion process has been a subject of considerable study. Two main forces have been emphasized. First, potential technology adopters are heterogeneous, so that a technology that is generally superior will not be equally superior for all potential users, and may remain inferior to existing technology for some users for an extended period of time after its introduction. Second, adopting a new technology is a risky under- 
taking, requiring considerable information, both about the generic attributes of the new technology and about the details of its use in the particular application being considered. It takes time for information to diffuse sufficiently, and the diffusion of the technology is limited by this process of diffusion of information.

The two main models of the diffusion process each emphasize one of these two aspects of the process. The probit or rank model, first articulated in an unpublished paper by David (1969), posits that potential adopters are characterized by a distribution of returns associated with the new technology. Because adoption is costly, at any moment in time there is a threshold point on this distribution, such that potential users with values above this threshold will want to adopt, and users for whom the value of the new technology is at or below this threshold will not want to adopt. Because the new technology will typically get cheaper and better as time passes, this threshold will gradually move to the left, and eventually sweep out the entire distribution. If the distribution of underlying values is normal (or another single-peaked distribution with similar shape), this gradual movement of the threshold across the distribution will produce the typical S-shaped diffusion curve.

The other widely-used model is the epidemic model (Griliches 1957; Stoneman 1983). The epidemic model presumes that the primary factor limiting diffusion is information, and that the most important source of information about a new technology is people or firms who have tried it. Thus technology spreads like a disease, with the instigation of adoption being contact between the "infected" population (people who have already adopted) and the uninfected population. Denoting the fraction of the potential using population that has adopted as $f$, this leads to the differential equation $\frac{d f}{d t}=\beta f(1-f)$. Solution of this equation yields a logistic function, which has the characteristic S-shape. The parameter $\beta$ captures the "contagiousness" of the disease, presumably related to the cost of the new technology and the degree of its superiority over the technology it replaces (Griliches 1957). ${ }^{6}$

Both of the models discussed above predict that the present value of benefits from adoption and the initial adoption cost enter into decisions affecting the diffusion rate. In the probit model, this net present value comparison determines the location of the adoption threshold that determines what fraction of potential adopters will adopt at a moment in time. In the epidemic model, this net present value comparison determines the magnitude of the "contagiousness" parameter, which in turn determines the speed at which the technology spreads from adopters to previous non-adopters.

While the induced innovation literature focuses on the potential for environmental policy to bring forth new technology through innovation, there is also a widely-held view that significant reductions in environmental impacts could be achieved through more widespread diffusion of existing economically-attractive technologies, particularly ones that increase energy efficiency and thereby reduce emissions associated with fossil fuel combustion. For example, the report of the 
Interlaboratory Working Group (1997) compiled an analysis of technologies that reportedly could reduce energy use and hence $\mathrm{CO}_{2}$ emissions at low or even negative net cost to users. The observation that energy-efficient technologies that are cost-effective at current prices are diffusing only slowly dates to the 1970s, having been identified as a "paradox" at least as far back as Shama (1983).

The apparent potential for emissions reductions associated with faster diffusion of existing technology raises two important questions. First, what is the theoretical and empirical potential for "induced diffusion" of lower-emissions technologies? Specifically, how do environmental policy instruments that implicitly or explicitly increase the economic incentive to reduce emissions affect the diffusion rate of these technologies? A second and related question is the degree to which historical diffusion rates have been limited by market failures in the energy and equipment markets themselves (Jaffe and Stavins 1994). To the extent that diffusion has been and is limited by market failures, it is less clear that policies that operate by increasing the economic incentive to adopt such technology will be effective. On the other hand, if such market failures are important, then policies focused directly on correction of such market failures provide, at least in principle, opportunities for policy interventions that are social-welfare increasing, even without regard to any environmental benefit. Potential sources of market failure include problems regarding inadequate information and uncertainty, principal-agent problems, constrained capital financing, and positive adoption spillovers.

Information plays a particularly important role in the technology diffusion process. First, information is a public good that may be expected in general to be underprovided by markets. Second, to the extent that the adoption of the technology by some users is itself an important mode of information transfer to other parties, adoption creates a positive externality and is therefore likely to proceed at a socially suboptimal rate. As discussed further in Section 3.2, Howarth et al. (2000) explored the significance of inadequate information in inhibiting the diffusion of more efficient lighting equipment. Metcalf and Hassett (1999) compared available estimates of energy savings from new equipment to actual savings realized by users who have installed the equipment. They found that actual savings, while significant, were less than those promised by engineers and product manufacturers.

Also related to imperfect information are a variety of agency problems that can inhibit the adoption of superior technology. An example of an external agency problem would be a landlord/tenant relationship, in which a tenant pays for utilities but the landlord makes decisions regarding which appliances to purchase, or vice versa. Internal agency problems can arise in organizations where the individual or department responsible for equipment purchase or maintenance differs from the individual or department whose budget covers utility costs. ${ }^{7}$ DeCanio (1998) explored the significance of organizational factors in explaining firms' perceived returns to installation of energy-efficient lighting.

Uncertainty is another factor that may limit the adoption of new technology (Geroski 2000). Such uncertainty is not a market failure, merely a fact of economic 
life. Uncertainty can be inherent in the technology itself, in the sense that its newness means that users are not sure how it will perform (Mansfield 1968). For resource-saving technology, there is the additional uncertainty that the economic value of such savings depends on future resource prices, which are themselves uncertain. This uncertainty about future returns means that there is an "option value" associated with postponing the adoption of new technology (Pindyck 1991; Hassett and Metcalf 1995, 1996).

Closely related to the issue of uncertainty is the issue of the discount rate or investment hurdle rate used by purchasers in evaluating the desirability of new technology. A large body of research demonstrates that purchasers appear to use relatively high discount rates in evaluating energy-efficiency investments (Hausman 1979; Ruderman et al. 1987; Ross 1990). The implicit or explicit use of relatively high discount rates for energy savings does not represent a market failure in itself; it is rather the manifestation of underlying aspects of the decision process including those just discussed. At least some portion of the discount rate premium is likely to be related to uncertainty, although the extent to which the premium can be explained by uncertainty and option value is subject to debate (Hassett and Metcalf 1995, 1996; Sanstad et al. 1995).

Capital market failures that make it difficult to secure external financing for these investments may also play a role (Shrestha and Karmacharya 1998). For households and small firms, adoption of new technologies with significant capital costs may be constrained by inadequate access to financing. And in some countries, import barriers may inhibit the adoption of technology embodied in foreignproduced goods (Reppelin-Hill 1999). It is impossible to generalize, however, particularly across countries.

Finally, the presence of increasing returns in the form of learning effects, network externalities, or other positive adoption externalities suggests that market outcomes for technologies exhibiting these features may be inefficient. For example, the idea that we are "locked into" a fossil-fuel-based energy system is a recurring theme in policy discussions regarding climate change and other energyrelated environmental problems. At a more aggregate level, there has been much discussion of the question of whether it is possible for developing countries to take less environmentally-damaging paths of development than have industrialized countries (Evenson 1995).

\section{Theory of the Effects of Environmental Policy on Technological Change}

The effects of environmental policies on the development and spread of new technologies may, in the long run, be among the most important determinants of success or failure of environmental protection efforts (Kneese and Schultze 1975). It has long been recognized that alternative types of environmental policy instruments can have significantly different effects on the rate and direction of technological change (Orr 1976). Environmental policies, particularly those with large economic impacts 
(for example, those intended to address global climate change) can be designed to foster rather than inhibit technological invention, innovation, and diffusion (Kempe and Soete 1990).

For purposes of examining the link between environmental policy instruments and technological change, policies can be characterized as either command-andcontrol or market-based approaches. Market-based instruments - such as pollution charges, subsidies, tradeable permits, and some types of information programs - can encourage firms or individuals to undertake pollution control efforts that are in their own interests and that collectively meet policy goals (Stavins 2001). Command-and-control regulations tend to force firms to take on similar shares of the pollution-control burden, regardless of the cost. They often do this by setting uniform standards for firms, the most prevalent of which are performanceand technology-based standards. But holding all firms to the same target can be expensive and, in some circumstances, counterproductive, since standards typically exact relatively high costs by forcing some firms to resort to unduly expensive means of controlling pollution. Because the costs of controlling emissions may vary greatly among firms, and even among sources within the same firm, the appropriate technology in one situation may not be cost-effective in another.

All of these forms of intervention have the potential for inducing or forcing some amount of technological change, because by their very nature they induce or require firms to do things they would not otherwise do. Performance and technology standards can be explicitly designed to be "technology forcing," mandating performance levels that are not currently viewed as technologically feasible or mandating technologies that are not fully developed. One problem with these approaches, however, is that while regulators can typically assume that some amount of improvement over existing technology will always be feasible, it is impossible to know how much. Standards must either be made unambitious, or else run the risk of being ultimately unachievable, leading to political and economic disruption (Freeman and Haveman 1972).

Technology standards are particularly problematic, since they tend to freeze the development of technologies that might otherwise result in greater levels of control. Under regulations that are targeted at technologies, as opposed to emissions levels, no financial incentive exists for businesses to exceed control targets, and the adoption of new technologies is discouraged. Under a "Best Available Control Technology" (BACT) standard, a business that adopts a new method of pollution abatement may be "rewarded" by being held to a higher standard of performance and thereby not benefit financially from its investment, except to the extent that its competitors have even more difficulty reaching the new standard (Hahn and Stavins 1991). On the other hand, if third parties can invent and patent better equipment, they can - in theory - have a ready market. Under such conditions, a BACT type of standard can provide a positive incentive for technology innovation. Unfortunately, as we note below, there has been very little theoretical or empirical analysis of such technology-forcing regulations. 
In contrast with such command-and-control regulations, market-based instruments can provide powerful incentives for companies to adopt cheaper and better pollution-control technologies. This is because with market-based instruments, it pays firms to clean up a bit more if a sufficiently low-cost technology or process for doing so can be identified and adopted. ${ }^{8}$

There are two principal ways in which environmental policy instruments can be compared with regard to their effects on technological change. First, one can ask - both with theoretical models and with empirical analyses - what effects alternative instruments have on the rate and direction of relevant technological change. Second, one can ask whether environmental policies encourage an efficient rate and direction of technological change, or more broadly, whether such policies result in overall economic efficiency (that is, whether the efficient degree of environmental protection is achieved). We consider both sets of criteria.

\subsection{TECHNOLOGY INVENTION AND INNOVATION}

Although decisions about technology invention and commercialization are partly a demand-side function of anticipated sales (adoption), the relevant literature comparing the effects of alternative environmental policy instruments has given greater attention to the supply side, focusing on incentives for firm-level decisions to incur R\&D costs in the face of uncertain outcomes. Such R\&D can be either inventive or innovative, but the theoretical literature in this area typically makes no particular distinction.

The earliest work that is directly relevant was by Magat (1978), who compared effluent taxes and CAC standards using an innovation possibilities frontier (IPF) model of induced innovation, where research can be used to augment capital or labor in a standard production function. Subsequently, Magat (1979) compared taxes, subsidies, permits, effluent standards, and technology standards, and showed that all but technology standards would induce innovation biased toward emissions reduction. ${ }^{9}$

Taking a somewhat broader view than most economic studies, Carraro and Siniscalco (1994) suggested that environmental policy instruments should be viewed jointly with traditional industrial policy instruments in determining the optimal way to attain a given degree of pollution abatement. They showed that innovation subsidies can be used to attain the same environmental target, but without the output reductions that result from pollution taxes. Laffont and Tirole (1996) examined how a tradeable permit system could - in theory - be modified to achieve desired incentive effects for technological change. They demonstrated that although spot markets for permits cannot induce the socially optimal degree of innovation, futures markets can improve the situation (Laffont and Tirole 1996). ${ }^{10}$

Cadot and Sinclair-Desgagne (1996) posed the following question: if a regulated industry has private information on the costs of technological advances in pollution control (frequently a reasonable assumption), then since the industry 
has an incentive to claim that such technologies are prohibitively expensive, can the government design an incentive scheme that will avoid the problems posed by this information asymmetry? The authors developed a solution to this gametheoretic problem. Not surprisingly, the scheme involves government issued threats of regulation (which diminish over time as the firm completes stages of technology development).

It was only recently that theoretical work followed up on Magat's attempt in the late 1970s to rank policy instruments according to their innovation-stimulating effects. Fischer et al. (1998) found that an unambiguous ranking of policy instruments was not possible. Rather, the ranking of policy instruments depended on the innovator's ability to appropriate spillover benefits of new technologies to other firms, the costs of innovation, environmental benefit functions, and the number of firms producing emissions.

In an analysis that is quite similar in its results to the study by Fischer et al. (1998), Ulph (1998) compared the effects of pollution taxes and command-andcontrol standards, and found that increases in the stringency of the standard or tax had ambiguous effects on the level of $\mathrm{R} \& \mathrm{D}$, because environmental regulations have two competing effects: a direct effect of increasing costs, which increases the incentives to invest in R\&D in order to develop cost-saving pollution-abatement methods; and an indirect effect of reducing product output, which reduces the incentive to engage in R\&D. Carraro and Soubeyran (1996) compared an emission tax and an R\&D subsidy, and found that an R\&D subsidy is desirable if the output contractions induced by the tax are small or if the government finds output contractions undesirable for other reasons. Addressing the same trade-off, Katsoulacos and Xepapadeas (1996) found that a simultaneous tax on pollution emissions and subsidy to environmental R\&D may be better suited to overcoming the joint market failure (negative externality from pollution and positive externality or spillover effects of R\&D). ${ }^{11}$ Finally, Montero (2000) compared instruments under noncompetitive circumstances, and found that the results are less clear than when perfect competition is assumed. Standards and taxes yield higher incentives for $\mathrm{R} \& \mathrm{D}$ when the market is characterized by Cournot competition, but the opposite holds when the market is characterized by Bertrand competition.

\subsection{TECHNOLOGY DIFFUSION}

The predominant theoretical framework for analyses of diffusion effects has been what could be called the "discrete technology choice" model: firms contemplate the use of a certain technology which reduces marginal costs of pollution abatement and which has a known fixed cost associated with it. While some authors have presented this approach as a model of "innovation," it is more appropriately viewed as a model of adoption. With such models, several theoretical studies have found that the incentive for the adoption of new technologies is greater under marketbased instruments than under direct regulation (Zerbe 1970; Downing and White 
1986; Milliman and Prince 1989; Jung et al. 1996). With the exception of Downing and White (1986), all of these studies examined the gross impacts of alternative policy instruments on the quantity of technology adoption.

Theoretical comparisons among market-based instruments have produced only limited agreement. In a frequently-cited article, Milliman and Prince (1989) examined firm-level incentives for technology diffusion provided by five instruments: command-and-control; emission taxes; abatement subsidies; freelyallocated emission permits, and auctioned emission permits. Firm-level incentives for adoption in this representative-firm model were pictured as the anticipated change in producer surplus. They found that auctioned permits would provide the largest adoption incentive of any instrument, with emissions taxes and subsidies second, and freely allocated permits and direct controls last. The Milliman and Prince (1989) study was criticized by Marin (1991) because of its assumption of identical firms, but it was subsequently shown that the results remain largely unchanged with heterogeneous abatement costs (Milliman and Prince 1992).

In 1996, Jung et al. built on Milliman and Prince's basic framework for comparing the effects of alternative policy instruments, but rather than focusing on firm-level changes in producer surplus, they considered heterogeneous firms, and modeled the "market-level incentive" created by various instruments. Their rankings echoed those of Milliman and Prince (1989): auctioned permits provided the greatest incentive, followed by taxes and subsidies, free permits, and performance standards.

Subsequent theoretical analyses (Parry 1998; Denicolò 1999; Keohane 1999) clarified several aspects of these rankings. First, there is the question of relative firm-level incentives to adopt a new, cost-saving technology when the price of pollution (permit price or tax level) is endogenous. Milliman and Prince (1989), as well as Jung et al. (1996), argued that auctioned permits would provide greater incentives for diffusion than freely-allocated permits, because technology diffusion lowers the equilibrium permit price, bringing greater aggregate benefits of adoption in a regime where all sources are permit buyers. But when technology diffusion lowers the market price for tradeable permits, all firms benefit from this lower price regardless of whether they adopt the given technology (Keohane 1999). Thus, if firms are price takers in the permit market, auctioned permits provide no more adoption incentive than freely-allocated permits.

The overall result is that both auctioned and freely-allocated permits are inferior in their diffusion incentives to emission tax systems (but superior to commandand-control instruments). Under tradeable permits, technology diffusion lowers the equilibrium permit price, thereby reducing the incentive for participating firms to adopt. Thus, a permit system provides a lower adoption incentive than a tax, assuming the two instruments are equivalent before diffusion occurs (Denicolò 1999; Keohane 1999).

More broadly, it appears that an unambiguous exhaustive ranking of instruments is not possible on the basis of theory alone. Parry (1998) found that the welfare 
gain induced by an emissions tax is significantly greater than that induced by tradable permits only in the case of very major innovations. Similarly, Requate (1998) included an explicit model of the final output market, and finds that whether (auctioned) permits or taxes provide stronger incentives to adopt an improved technology depends upon empirical values of relevant parameters.

Furthermore, complete theoretical analysis of the effects of alternative policy instruments on the rate of technological change must include modeling of the government's response to technological change, because the degree to which regulators respond to technologically-induced changes in abatement costs affects the magnitude of the adoption incentive associated with alternative policy instruments. Because technology diffusion presumably lowers the aggregate marginal abatement cost function, it results in a change in the efficient level of control. Hence, following diffusion, the optimal agency response is to set a more ambitious target. Milliman and Prince (1989) examined the incentives facing private industry, under alternative policy instruments, to oppose such policy changes. Their conclusion was that firms would oppose optimal agency adjustment of the policy under all instruments except taxes. Under an emissions tax, the optimal agency response to cost-reducing technological change is to lower the tax rate (assuming convex damages); under a subsidy, the optimal response is to lower the subsidy; under tradeable permit systems, the optimal response is to decrease the number of available permits, and thereby drive up the permit price. Thus, firms have clear incentives to support the optimal agency response only under an emissions tax regime.

In a comparison of tradeable permits and pollution taxes, Biglaiser et al. (1995) examined these instruments' ability to achieve the first-best outcome in a dynamic setting. They found that effluent taxes can do so, but permits cannot, but that this result depends on an assumption of constant marginal damages. If marginal damages are not constant, the optimal policy is determined by the interaction of marginal damages and marginal abatement costs for both taxes and permits. The result is analogous to Weitzman's (1974) rule: if the marginal damage curve is relatively flat and there is uncertainty in marginal costs (from the regulator's perspective) due to potential innovation at the firm level, then a price instrument is more efficient.

\subsection{INDUCED INNOVATION AND OPTIMAL ENVIRONMENTAL POLICY}

It seems logical that if environmental policy intervention induces innovation, this reduces the social cost of environmental regulation, suggesting that the optimal policy is more stringent than it would be if there were no induced innovation. This intuition contains an element of truth, but a number of complexities arise. First, one has to be careful what is meant by reducing the cost of regulation. If the policy intervention induces a reduction in the marginal cost of abatement, then any given policy target (for example, a particular aggregate emission rate or a particular 
ambient concentration) will be achieved at lower cost than it would without induced innovation. On the other hand, the lower marginal abatement cost schedule arising from induced innovation makes it socially optimal to achieve a greater level of pollution abatement. For a flat marginal social benefit function evaluated at the social optimum, or for any emission tax, this results in greater total expenditure on abatement even as the marginal abatement cost falls.

Another important issue is the general equilibrium effect of induced environmental innovation on innovation elsewhere in the economy (Schmalensee 1994). If inducement operates through increased $R \& D$ expenditure, then an issue arises as to the elasticity of supply of $R \& D$ inputs. To the extent that this supply is inelastic, then any induced innovation must come at the expense of other forms of innovation, creating an opportunity cost that may negate the effects observed in the regulated portion of the economy. The general equilibrium consequences of these effects for welfare analysis depend on the extent of $\mathrm{R} \& \mathrm{D}$ spillovers or other market failures, and the magnitude of these distortions in the regulated firms or sectors relative to the rest of the economy (Goulder and Schneider 1999).

In an application to global climate policy, Goulder and Mathai (2000) looked at optimal carbon abatement in a dynamic setting, considering not only the optimal overall amount of abatement but also its timing. In addition to R\&D-induced innovation, they considered (in a separate model) reductions in abatement costs that come about via learning-by-doing. Induced innovation reduces marginal abatement costs, which increases the optimal amount of abatement, but it also increases the cost of abatement today relative to the future, because of lower abatement costs in the future, implying that with R\&D-induced innovation, optimal abatement is lower in early years and higher in later years than it would otherwise be. In the learning-by-doing model, there is a third effect: abatement today lowers the cost of abatement in the future. This reinforces the tendency for cumulative optimal abatement to be higher in the presence of induced innovation, but makes the effect on optimal near-term abatement ambiguous. ${ }^{12}$

\section{Empirics of the Innovation and Diffusion of Green Technology}

\subsection{EMPIRICAL ANALYSIS OF INNOVATION}

There has been exceptionally little empirical analysis directly of the effects of alternative policy instruments on technology innovation in pollution abatement, principally because of the paucity of available data. One study by Bellas (1998) carried out a statistical analysis of the costs of flue gas desulfurization (scrubbing) installed at coal-fired power plants in the United States under the new-source performance standards of the 1970 and 1977 Clean Air Acts, but failed to find any evidence of effects of scrubber vintage on cost, suggesting little technological innovation had taken place under this regulatory regime.

Although there has been very little analysis in the context of pollutionabatement technologies, there is a more extensive literature on the effects of 
alternative policy instruments on the innovation of energy-efficiency technologies, because data have been available. The greatest challenge in testing the induced innovation hypothesis specifically with respect to environmental inducement is the difficulty of measuring the extent or intensity of inducement across firms or industries (Jaffe et al. 1995). Ideally, one would like to look at the relationship between innovation and the shadow price of pollution or environmental inputs, but such shadow prices are not easily observed. Instead, one must use proxies, such as expenditures on pollution abatement, prices of polluting inputs, and characteristics of environmental regulations. ${ }^{13}$ We consider studies that have used each of these approaches.

Lanjouw and Mody (1996) showed a strong association between pollution abatement expenditures and the rate of patenting in related technology fields. Jaffe and Palmer (1997) examined the correlation between pollution expenditures by industry and indicators of innovation more broadly. They found that there is a significant correlation within industries over time between the rate of expenditure on pollution abatement and the level of R\&D spending. They did not, however, find evidence of an effect of pollution control expenditure on overall patenting.

Evidence of inducement has also been sought by examining the response to changing energy prices. Newell et al. (1999) examined the extent to which the energy efficiency of the menu of home appliances available for sale changed in response to energy prices between 1958 and 1993, using a model of induced innovation as changing characteristics of capital goods. Newell et al. (1999) generalized Hicks' (1932) concept of induced innovation (in terms of factor prices) to include inducement by regulatory standards, such as labeling requirements that might increase the value of certain product characteristics by making consumers more aware of them. More generally, non-price regulatory constraints can fit within the inducement framework if they can be modeled as changing the shadow or implicit price that firms face in emitting pollutants. In their framework, the existing technology for making a given type of equipment at a point in time is identified in terms of vectors of characteristics (including cost of manufacture) that are feasible. The process of invention makes it possible to manufacture "models" (characteristics vectors) that were previously infeasible. Innovation means the offering for commercial sale of a model that was not previously offered for sale. Induced innovation is then represented as movements in the frontier of feasible models that reduce the cost of energy efficiency in terms of other attributes.

With this product-characteristic approach, Newell et al. (1999) assessed the effects of changes in energy prices and in energy-efficiency standards in stimulating innovation, and found that energy price changes induced both commercialization of new models and elimination of old models. Regulations, however, worked largely through energy-inefficient models being dropped, since that is the intended effect of the energy-efficiency standards (models below a certain energy efficiency level may not be offered for sale). Through econometric estimation and a series of dynamic simulations, Newell et al. (1999) examined the effects of energy price changes and 
efficiency standards on average efficiency of the menu of products over time. They found that a substantial amount of the improvement was what may be described as autonomous (that is, not otherwise explained by the model and associated with the passage of time), but significant amounts of innovation were also due to changes in energy prices and changes in energy-efficiency standards. They found that technological change in air conditioners was actually biased against energy efficiency in the 1960s (when real energy prices were falling), but that this bias was reversed after the two energy shocks of the 1970s. In terms of the efficiency of the average model offered, they found that energy efficiency in 1993 would have been about one-quarter to one-half lower in air conditioners and gas water heaters, if energy prices had stayed at their 1973 levels, rather than following their historical path. Most of the response to energy price changes came within less than five years of those changes.

A closely related approach to investigating the same phenomena is that of hedonic price functions. One hedonic study examined the effects of public policies in the context of home appliances. Greening et al. (1997) estimated the impacts of the 1990 and 1993 national efficiency standards on the quality-adjusted price of household refrigerator/freezer units, and found that quality-adjusted prices fell after the implementation of the energy efficiency standards. However, such qualityadjusted price decreases are consistent with historical trends in refrigerator/freezer prices, and hence, one cannot rule out the possibility that the imposition of efficiency standards slowed the rate of quality-adjusted price decline.

Given the attention paid to automobile fuel economy over the past two decades, it is not surprising that several hedonic studies of automobiles have addressed or focused on energy-efficiency, including Ohta and Griliches (1976) and Goodman (1983). Atkinson and Halvorsen (1984) found that the fuel efficiency of the new car fleet responds more than proportionally to changes in expected fuel prices. Using an analogue to the hedonic price technique, Wilcox (1984) constructed a qualityadjusted measure of automobile fuel economy over the period 1952-1980, finding that it was positively related to oil prices. Ohta and Griliches (1986) found that gasoline price changes over the period 1970-1981 could alone explain much of the observed change in related automobile characteristics.

More recently, Pakes et al. (1993) investigated the effects of gasoline prices on the fuel economy of motor vehicles offered for sale, and found that the observed increase in miles per gallon (mpg) from 1977 onward was largely due to the consequent change in the mix of vehicles on the market. Fewer low-mpg cars were marketed, and more high-mpg cars were marketed. Subsequently, Berry et al. (1996) combined plant-level cost data for the automobile industry and information on the characteristics of models that were produced at each plant to estimate a hedonic cost function - the supply-side component of the hedonic price function finding that quality-adjusted costs generally increased over the period 1972-1982, thus coinciding with rising gasoline prices and emission standards. 
Goldberg (1998) combined a demand-side model of discrete vehicle choice and utilization with a supply-side model of oligopoly and product differentiation to estimate the effects of CAFE (Corporate Average Fuel Economy) standards on the fuel economy of the new car fleet. She found that automobile fuel operating costs have had a significant effect, although a gasoline tax of a magnitude that could match the effect of CAFE on fuel economy would have to be very large.

Finally, Popp (2001a, b) looked more broadly at energy prices and energyrelated innovation. In the first paper, he found that patenting in energy-related fields increases in response to increased energy prices, with most of the effect occurring within a few years, and then fading over time. Popp attributed this fading to diminishing returns to $\mathrm{R} \& \mathrm{D}$. In the second paper, he attempted to decompose the overall reduction in energy use that is associated with changing energy prices between the substitution effect - movements along a given production frontier and the induced innovation effect - movement of the production frontier itself induced by the change in energy prices. Using energy-related patents as a proxy for energy innovation, he found that approximately one-third of the overall response of energy use to prices is associated with induced innovation, with the remaining two-thirds associated with factor substitution. Because energy patents are likely to measure energy innovation only with substantial error, one might interpret this result as placing a lower bound on the fraction of the overall response of energy use to changing prices that is associated with innovation.

\subsection{EMPIRICAL ANALYSIS OF DIFFUSION}

One of the great successes during the modern era of environmental policy was the phasedown of lead in gasoline, which took place in the United States principally during the decade of the 1980s. The phasedown was accomplished through a tradeable permit system among refineries, whereby lead rights could be exchanged and/or banked for later use. Kerr and Newell (2000) used a duration model to assess the effects of the phasedown program on technology diffusion. They found that increased stringency (which raised the effective price of lead) encouraged greater adoption of technology that substitutes for lead in increasing octane. They also found that larger and more technically sophisticated refineries, which had lower costs of adoption, were more likely to adopt the new technology. As theory suggests (Malueg 1989), they also found that the tradeable permit system provided incentives for more efficient technology adoption decisions, as evidenced by a significant divergence in the adoption behavior of refineries with low versus high compliance costs. Namely, the positive differential in the adoption propensity of expected permit sellers (i.e., low-cost refineries) relative to expected permit buyers (i.e., high-cost refineries) was significantly greater under market-based lead regulation compared to under individually binding performance standards.

Another prominent application of tradeable permit systems which has provided an opportunity for empirical analysis of the effects of policy instruments on tech- 
nology diffusion is the sulfur dioxide allowance trading program, initiated under the U.S. Clean Air Act amendments of 1990. In an econometric analysis, Keohane (2001) found evidence that the increased flexibility of the market-based instrument provided greater incentives for technology adoption. In particular, he found that the choice of whether or not to adopt a "scrubber" to remove sulfur dioxide - rather than purchasing (more costly) low-sulfur coal - was more sensitive to cost differences (between scrubbing and fuel-switching) under the tradeable permit system than under the earlier emissions rate standard. ${ }^{14}$

Turning from pollution abatement to energy efficiency, Jaffe and Stavins (1995) carried out econometric analyses of the factors affecting the adoption of thermal insulation technologies in new residential construction in the United States between 1979 and 1988. They examined the dynamic effects of energy prices and technology adoption costs on average residential energy-efficiency technologies in new home construction, and found that the response of mean energy efficiency to energy price changes was positive and significant, both statistically and economically. Interestingly, they also found that equivalent percentage adoption cost changes were about three times as effective as energy price changes in encouraging adoption, although standard financial analysis would suggest they ought to be about equal in percentage terms. This finding offers confirmation for the conventional wisdom that technology adoption decisions are more sensitive to up-front cost considerations than to longer-term operating expenses.

Hassett and Metcalf (1995) found an even larger discrepancy between the effect of changes in installation cost and changes in energy prices. There are three possible explanations for this. One possibility is a behavioral bias that causes purchasers to focus more on up-front cost than they do on the lifetime operating costs of an investment. An alternative view is that purchasers focus equally on both, but uncertainty about future energy prices makes them give less weight to energy prices than they do to capital cost, which is known. A final interpretation might be that consumers have reasonably accurate expectations about future energy prices, and their decisions reflect those expectations, but our proxies for their expectations are not correct.

Although empirical evidence from these two studies indicate that subsidies may be more effective than "equivalent" taxes in encouraging technology diffusion, it is important to recognize some disadvantages of such subsidy approaches. First, unlike energy prices, adoption subsidies do not provide incentives to reduce utilization. Second, technology subsidies and tax credits can require large public expenditures per unit of effect, since consumers who would have purchased the product even in the absence of the subsidy still receive it. In the presence of fiscal constraints on public spending, this raises questions about the feasibility of subsidies that would be sizable enough to have desired effects.

Rose and Joskow (1990) also found a positive effect of fuel price increases on the adoption of a new fuel-saving technology in the U.S. electricity-generation sector; and in a tobit analysis of steel plant adoption of different furnace techno- 
logies, Boyd and Karlson (1993) found a significant positive effect of increases in a fuel's price on the adoption of technology that saves that fuel, although the magnitude of the effect was modest. For a sample of industrial plants in four heavily polluting sectors (petroleum refining, plastics, pulp and paper, and steel), Pizer et al. (2001) found that both energy prices and financial health were positively related to the adoption of energy-saving technologies.

Greene (1990) used data on fuel prices and fuel economy of automobiles from 1978 to 1989 to test the relative effectiveness of CAFE standards and gasoline prices in increasing fuel economy. He found that the big three U.S. firms faced a binding CAFE constraint, and for these firms compliance with CAFE standards had roughly twice the impact on fuel economy as did fuel prices. Japanese firms, however, did not face a binding CAFE constraint, and fuel prices had only a small effect. Luxury European manufactures seemed to base their fuel efficiency largely on market demand and often exceeded CAFE requirements. For these firms, neither the standards nor prices seemed to have much effect.

Another body of research has examined the effects on technology diffusion of command-and-control environmental standards when they are combined with "differential environmental regulations." In many situations where command-andcontrol standards have been used, the required level of pollution abatement has been set at a far more stringent level for new sources than for existing ones. There is empirical evidence that such differential environmental regulations have lengthened the time before plants were retired (Maloney and Brady 1988; Nelson et al. 1993). Further, this dual system can actually worsen pollution by encouraging firms to keep older, dirtier plants in operation (Stewart 1981; Gollop and Roberts 1983; McCubbins et al. 1989).

What about conventional command-and-control approaches? Jaffe and Stavins (1995) also examined the effects of more conventional regulations on technology diffusion, in the form of state building codes. They found no discernable effects. It is unclear to what extent this is due to inability to measure the true variation across states in the effectiveness of codes, or to codes that were in many cases not binding relative to typical practice. This is a reminder, however, that although price-based policies will always have some effect, typical command-and-control may have little effect if they are set below existing standards of practice. ${ }^{15}$

Attention has also been given to the effects on energy-efficiency technology diffusion of voluntary environmental programs. Howarth et al. (2000) examined two voluntary programs of the U.S. Environmental Protection Agency, the Green Lights and Energy Star programs, both of which are intended to encourage greater private industry use of energy-saving technologies. A natural question from economics is why would firms carry out additional technology investments as part of a voluntary agreement? The authors respond that there are a set of agency problems that inhibit economically wise adoption of some technologies. For example, most energy-saving investments are small, and senior staff may rationally choose to restrict funds for small projects that cannot be perfectly monitored. The Green 
Lights program may be said to attempt to address this type of agency problem by providing information on savings opportunities at the level of the firm where decisions are made.

Although the empirical literature on the effects of policy instruments on technology diffusion by no means settles all of the issues that emerge from the related theoretical studies, a consistent theme that runs through both the pollution-abatement and energy-efficiency empirical analyses is that market-based instruments are decidedly more effective than command-and-control instruments in encouraging the cost-effective adoption and diffusion of relevant new technologies.

\section{Conclusions}

Virtually all research on the relationship between technological change and environmental policy has been linked with one of two underlying realities: first, the environmental impacts of social and economic activity is greatly affected by the rate and direction of technological change; and second, environmental policy interventions themselves create new constraints and incentives that affect the process of technological developments.

One important research need, linked with the first reality, is the frequent necessity of determining the economic and environmental baseline against which to measure the impacts of proposed policies. Forecasts based on historical experience depend on the relative magnitude of the effects of price-induced technological change, learning-by-doing, public sector $\mathrm{R} \& \mathrm{D}$, and exogenous technical progress. Sorting out these influences with respect to environmentally relevant technologies and sectors poses a major challenge.

There has also been much debate surrounding the "win-win" hypothesis. Much of this debate has been explicitly or implicitly ideological or political. More useful would be detailed examinations regarding the kinds of policies and the kinds of private-sector institutions that are most likely to generate innovative, low-cost solutions to environmental problems.

More research is also needed on the second broad linkage between technology and environment, the effect of environmental policy interventions on the process of technological change. The empirical evidence is generally consistent with theoretical findings that market-based instruments for environmental protection are likely to have significantly greater, positive impacts over time than commandand-control approaches on the invention, innovation, and diffusion of desirable, environmentally-friendly technologies. But empirical studies have also produced some results that appear not to be consistent with theoretical expectations, such as the finding from two independent analyses that the diffusion of energy-efficiency technologies is more sensitive to variation in adoption-cost than to commensurate energy price changes. Further theoretical and/or empirical work may resolve this apparent anomaly. 
Refutable hypotheses have emerged from theoretical models of alternative policy instruments, but most have not been tested rigorously with empirical data. Whereas the predictions from theory regarding the ranking of alternative environmental policy instruments is relatively consistent, most of the empirical analysis has focused on energy-efficient technologies, rather than pollution abatement technologies per se. The increased use of market-based instruments and performance-based standards brings with it information with which hypotheses regarding the effects of policy instruments on technology innovation and diffusion can be tested.

Finally, the long-term nature of policy challenges such as that posed by the threat of global climate change makes it all the more important that we improve our understanding of the effects of environmental policy on innovation and diffusion of new technology. What is clear is that many relevant issues cannot be resolved at a purely theoretical level or on the basis of aggregate empirical analysis alone. Serious investigation of induced technological change and its consequences for environmental policy requires going beyond studies that examine whether or not such effects exist, to carry out detailed analyses in a variety of sectors in order to understand the circumstances under which the effects are large or small. This will inevitably require research from multiple methodological viewpoints over an extended period of time.

\section{Acknowledgements}

We are grateful for valuable research assistance from Lori Snyder and helpful comments from Ernst Berndt, Karl-Göran Mäler, Lawrence Goulder, Nathaniel Keohane, Charles Kolstad, Ian Parry, Steven Polasky, David Popp, Vernon Ruttan, Manuel Trajtenberg, Jeffrey Vincent, and David Zilberman, but the authors alone are responsible for all remaining errors.

\section{Notes}

1. This formulation can be considered a first-order approximation to an arbitrary functional form for Equation (2). Higher-order approximations can also be implemented.

2. Data regarding R\&D expenditures of firms are available from the financial statements of publicly traded firms, if the expenditure is deemed "material" by the firm's auditors, or if the firm chooses for strategic reasons to report the expenditure (Bound et al. 1984). In the United States, the government carries out a "census" of R\&D activity, and reports totals for broad industry groups (National Science Board 1998). Many industrialized countries now collect similar statistics, which are available through the Organization of Economic Cooperation and Development (OECD 2000).

3. Typically, for there to be environmental impacts of a new technology, a fourth step is required utilization, but that is not part of the process of technological change per se. Thus, for example, a new type of hybrid motor vehicle engine might be invented, which emits fewer pollutants per mile; the same or another firm might commercialize this engine and place the innovation in new cars available for purchase on the market; individuals might purchase (or adopt) these cars, 
leading to diffusion of the new technology; and finally, by driving these cars instead of others (utilization), aggregate pollutant emissions might be reduced. Conversely, if higher efficiency and the resulting reduced marginal cost causes users to increase utilization, then the emissions reduction associated with higher efficiency may be partially or totally offset by higher utilization.

4. See, for example, Gollop and Roberts (1983), Kolstad and Turnovsky (1998) and Yaisawarng and Klein (1994).

5. For a survey, see Holmström and Tirole (1987).

6. Both the probit and epidemic models typically focus on the fraction of the population that had adopted at a point in time. If one has individual-level data on adopters, one can take as the dependent variable the individual time until adoption. This leads to a duration or hazard model (Rose and Joskow 1990). Kerr and Newell (2000) employed a duration model to analyze technology adoption decisions by petroleum refineries during the phasedown of lead in gasoline.

7. For a discussion of the implications of the separation of environmental decision-making in major firms from relevant economic signals, see: Hockenstein et al. (1997). A series of related case studies are provided by Reinhardt (2000).

8. In theory, the relative importance of the dynamic effects of alternative policy instruments on technological change (and hence long-term compliance costs) is greater in the case of those environmental problems which are of great magnitude (in terms of anticipated abatement costs) and/or very long time horizon. Hence, the increased attention being given by scholars and by policy makers to the problem of global climate change has greatly increased the prominence of the issues that are considered in this article.

9. A considerable amount of theoretical work followed in the 1980s. Although much of that work characterized its topic as the effects of alternative policy instruments on technology innovation, the focus was in fact on effects of policy on technology diffusion. Hence, we defer consideration of those studies to the next section.

10. In a subsequent analysis, Laffont and Tirole (1996) examined the government's ability to influence the degree of innovative activity by setting the number of permits (and permit prices) in various ways in a dynamic setting.

11. See, also, Conrad (2000).

12. Nordhaus (2000) introduced induced technological change into the "DICE" model of global climate change and associated economic activities, and found in that case that the impact of induced innovation was modest.

13. In the literature on the relationship between environmental regulation and productivity, discussed in section 1.3, to measure the characteristics of environmental regulations studies have used expert judgements about relative regulatory stringency in different states (Gray and Shadbegian 1998), number of enforcement actions (Gray and Shadbegian 1995), attainment status with respect to environmental laws and regulations (Greenstone 1998), and specific regulatory events (Berman and Bui 2001).

14. In an examination of the effects of alternative policy instruments for reducing oxygen-demanding water pollutants, Kemp (1998) found that effluent charges were a significant predictor of adoption of biological treatment by facilities. In earlier work, Purvis and Outlaw (1995) carried out a case study of EPA's permitting process for acceptable water-pollution control technologies in the U.S. livestock production sector.

15. In a separate analysis of thermal home insulation, this one in the Netherlands, Kemp (1997) found that a threshold model of diffusion (based on a rational choice approach) could not explain observed diffusion patterns. Instead, epidemic models provided a better fit to the data. Kemp also found that there was no significant effect of government subsidies on the adoption of thermal insulation by households. 


\section{References}

Arrow, K. J. (1962), 'Economic Welfare and the Allocation of Resources for Invention', in R. Nelson, ed., The Rate and Direction of Inventive Activity. Princeton NJ: Princeton University Press.

Atkinson, S. E. and R. Halvorsen (1984), 'A New Hedonic Technique for Estimating Attribute Demand: An Application to the Demand for Automobile Fuel Efficiency', Review of Economics and Statistics 66, 417-426.

Bellas, A. S. (1998), 'Empirical Evidence of Advances in Scrubber Technology', Resource and Energy Economics 20, 327-343.

Berman, E. and L. Bui (2001), 'Environmental Regulation and Productivity: Evidence from Oil Refineries', Review of Economics and Statistics 83(3), 498-510.

Berry, S., S. Kortum and A. Pakes (1996), 'Environmental Change and Hedonic Cost Functions for Automobiles', Proceedings of the National Academy of Sciences, U.S.A. 93, 12731-12738.

Biglaiser, G., J. K. Horowitz and J. Quiggin (1995), 'Dynamic Pollution Regulation', Journal of Regulatory Economics 8, 33-44.

Bound, J., C. Cummins, Z. Griliches, B. Hall and A. Jaffe (1984), 'Who Does R\&D and Who Patents?', in Z. Griliches, ed., $R \& D$, Patents and Productivity. Chicago: University of Chicago Press.

Boyd, G. A. and S. H. Karlson (1993), 'The Impact of Energy Prices on Technology Choice in the United States Steel Industry', The Energy Journal 14(2), 47-56.

Boyd, G. and J. McClelland (1999), 'The Impact of Environmental Constraints on Productivity Improvement and Energy Efficiency an Integrated Paper and Steel Plants', The Journal of Economics and Environmental Management 38, 121-146.

Boyd, G. and J. Pang (2000), 'Estimating the Linkage between Energy Efficiency and Productivity', Energy Policy 28, 289-296.

Cadot, O. and B. Sinclair-Desgagne (1996), 'Innovation Under the Threat of Stricter Environmental Standards', in C. Carraro et al., eds., Environmental Policy and Market Structure. Dordrecht: Kluwer Academic Publishers, pp. 131-141.

Carraro, C. and A. Soubeyran (1996), 'Environmental Policy and the Choice of Production Technology', in C. Carraro et al., eds., Environmental Policy and Market Structure. Dordrecht: Kluwer Academic Publishers, pp. 151-180.

Carraro, C. and D. Siniscalaco (1994), 'Environmental Policy Reconsidered: The Role of Technology Innovation', European Economic Review 38, 545-555.

Conrad, K (2000), 'Energy Tax and Competition in Energy Efficiency: The Case of Consumer Durables', Environmental and Resource Economics 15, 159-177.

David, P. (1966), 'The mechanization of reaping in the ante-bellum Midwest', in H. Rosovsky, ed., Industrialization in Two Systems. Cambridge, MA: Harvard University Press, pp. 3-39.

David, P. (1969), 'A Contribution to the Theory of Diffusion', mimeo. Forthcoming as Chapters 1-3 of David, P., Behind the Diffusion Curve. Boulder: Westview Press.

David, P., B. Hall and A. Toole (2000), 'Is Public R\&D a Complement or Substitute for Private R\&D? A Review of the Econometric Evidence', Research Policy 29, 497-529.

DeCanio, S. J. (1998), 'The Efficiency Paradox: Bureaucratic and Organizational Barriers to Profitable Energy-Saving Investments', Energy Policy 26, 441-454.

Denicolo, V. (1999), 'Pollution-reducing Innovations Under Taxes or Permits', Oxford Economic Papers 51, 184-199.

Downing, P. B. and L. J. White (1986), 'Innovation in Pollution Control', Journal of Environmental Economics and Management 13, 18-29.

Evenson, R. (1995), 'Technology Change and Technology Strategy', in J. Behrman and T.N. Srinivasan, eds., Handbook of Development Economics, Vol. 3A. Amsterdam: North-Holland. 
Fischer, C., I. W. H. Parry and W. A. Pizer (1998), 'Instrument Choice for Environmental Protection When Technological Innovation is Endogenous', Resources for the Future Discussion Paper 9904. Resources for the Future, Washington, D.C.

Freeman, A. M. and R. H. Haveman (1972), 'Clean Rhetoric and Dirty Water', Public Interest 28, 51-65.

Geroski, P. A. (1995), 'Markets for Technology: Knowledge, Innovation and Appropriability', in P. Stoneman, ed., Handbook of the Economics of Innovation and Technological Change. Oxford: Blackwell Publishers, pp. 90-131.

Geroski, P. A. (2000), 'Models of Technology Diffusion', Research Policy 29, 603-626.

Goldberg, P. K. (1998), 'The Effects of the Corporate Average Fuel Efficiency Standards in the U.S.', Journal of Industrial Economics 46, 1-3.

Gollop, F. M. and M. J. Roberts (1983), 'Environmental Regulations and Productivity Growth: The Case of Fossil-Fueled Electric Power Generation', Journal of Political Economy 91, 654-674.

Goodman, A. C. (1983), 'Willingness to Pay for Car Efficiency: A Hedonic Price Approach', Journal of Transport Economics 17, 247-266.

Goulder, L. H. and K. Mathai (2000), 'Optimal CO2 Abatement in the Presence of Induced Technological Change', Journal of Environmental Economics and Management 39, 1-38.

Goulder, L. H. and S. L. Schneider (1999), 'Induced Technological Change and the Attractiveness of $\mathrm{CO}_{2}$ Emissions Abatement Policies', Resource and Energy Economics 21, 211-253.

Gray, W. B. and R. J. Shadbegian (1995), 'Pollution Abatement Costs, Regulation, and Plant-Level Productivity', National Bureau of Economic Research Working Paper No. 4994.

Gray, W. B. and R. J. Shadbegian (1998), 'Environmental Regulation, Investment Timing, and Technology Choice', Journal of Industrial Economics 46, 235-256.

Greene, D. L. (1990), 'CAFE or Price?: An Analysis of the Effects of Federal Fuel Economy Regulations and Gasoline Price on New Car MPG, 1978-89', The Energy Journal 11(3), 37-57.

Greening, L. A., A. H. Sanstad and J. E. McMahon (1997), 'Effects of Appliance Standards on Product Price and Attributes: An Hedonic Pricing Model', Journal of Regulatory Economics 11, 181-194.

Greenstone, M. (1998), 'The Marginal Effects of Environmental Regulations of the Manufacturing Sector: Evidence from the 1970 and 1977 Clean Air Act Amendments', mimeo Princeton University.

Griliches, Z. (1957), 'Hybrid Corn: An Exploration in the Economics of Technical Change', Econometrica 48, 501-522.

Griliches, Z. (1979), 'Issues in Assessing the Contribution of Research and Development to Productivity Growth', Bell Journal of Economics 10, 92-116.

Griliches, Z. (1984), R\&D, Patents and Productivity. Chicago: University of Chicago Press.

Griliches, Z. (1992), 'The Search for R\&D Spillovers', Scandinavian Journal of Economics 94, S29S47.

Griliches, Z. (1998), R\&D and Productivity, The Econometric Evidence. Chicago: University of Chicago Press.

Grossman, G. and E. Helpman (1994), 'Endogenous Innovation in the Theory of Growth', Journal of Economic Perspectives 8, 23-44.

Hahn, R. W. and R. N. Stavins (1991), 'Incentive-based Environmental Regulation: a New Era from an Old Idea?', Ecology Law Quarterly 18, 1-42.

Hall, B., A. Jaffe and M. Trajtenberg (2000), 'Market Value and Patent Citations: A First Look', National Bureau of Economic Research Working Paper No. 7741.

Hassett, K. A. and G. E. Metcalf (1995), 'Energy Tax Credits and Residential Conservation Investment: Evidence form Panel Data', Journal of Public Economics 57, 201-217.

Hassett, K. A. and G. E. Metcalf (1996), 'Can Irreversibility Explain the Slow Diffusion of Energy Saving Technologies?', Energy Policy 24, 7-8. 
Hausman, J. A. (1979), 'Individual Discount Rates and the Purchase and Utilization of Energy-Using Durables', Bell Journal of Economics 10, 33.

Hicks, J. (1932), The Theory of Wages London: Macmillan.

Hockenstein, J. B., R. N. Stavins and B. W. Whitehead (1997), 'Creating the Next Generation of Market-Based Environmental Tools', Environment 39(4), 12-20, 30-33.

Holmström, B. R. and J. Tirole (1987), 'The Theory of the Firm', in R. Schmalensee and R. Willig, eds., Handbook of Industrial Organization, vol. 1. Amsterdam: North-Holland, pp. 61-133.

Howarth, R. B., B. M. Haddad, and B. Paton (2000), 'The Economics of Energy Efficiency: Insights from Voluntary Participation Programs', Energy Policy 28, 477-486.

Interlaboratory Working Group (1997), Scenarios of Carbon Reductions: Potential Impacts of Energy Technologies by 2010 and Beyond Washington: Office of Energy Efficiency and Renewable Technologies, U.S. Department of Energy.

Jaffe, A. B. (1986), 'Technological Opportunity and Spillovers of R\&D: Evidence from Firms' Patents, Profits and Market Value', American Economic Review 76, 984-1001.

Jaffe, A. B. (1998), 'The Importance of 'Spillovers' in the Policy Mission of the Advanced Technology Program', Journal of Technology Transfer, Summer, 11-19.

Jaffe, A. B. (2000), 'The U.S. Patent System in Transition: Policy Innovation and the Innovation Process', Research Policy 29, 531-558.

Jaffe, A. B. and K. Palmer (1997), 'Environmental Regulation and Innovation: A Panel Data Study', Review of Economics and Statistics 79, 610-619.

Jaffe, A. B. and R. N. Stavins (1994), 'The Energy Paradox and the Diffusion of Conservation Technology', Resource and Energy Economics 16, 91-122.

Jaffe, A. B. and R. N. Stavins (1995), 'Dynamic Incentives of Environmental Regulations: The Effects of Alternative Policy Instruments on Technology Diffusion', Journal of Environmental Economics \& Management 29, S43-S63.

Jaffe, A. B., S. Peterson, P. Portney and R. N. Stavins (1995), 'Environmental Regulation and the Competitiveness of U.S. Manufacturing: What Does the Evidence Tell Us?', Journal of Economic Literature 33, 132-163.

Jorgenson, D. (1990), 'Productivity and Economic Growth', in E. Berndt and J. Triplett, eds., Fifty Years of Economic Measurement. Chicago: University of Chicago Press, pp. 19-118.

Jorgenson, D. W. and K. J. Stiroh (2000), 'Raising the Speed Limit: U.S. Economic Growth in the Information Age', Brookings Papers on Economic Activity, 125-211.

Jung, C. H., K. Krutilla and R. Boyd (1996), 'Incentives for Advanced Pollution Abatement Technology at the Industry Level: An Evaluation of Policy Alternatives', Journal of Environmental Economics and Management 30, 95-111.

Karshenas, M. and P. Stoneman (1995), 'Technological Diffusion', in P. Stoneman, ed., Handbook of the Economics of Innovation and Technological Change. Oxford: Blackwell Publishers.

Katsoulacos, Y. and A. Xepapadeas (1996), 'Environmental Innovation, Spillovers and Optimal Policy Rules', in C. Carraro et al., eds., Environmental Policy and Market Structure. Dordrecht: Kluwer Academic Publishers, pp. 143-150.

Kemp, René (1997), Environmental Policy and Technical Change. Cheltenham, UK: Edward Elgar.

Kemp, René (1998), 'The Diffusion of Biological Waste-water Treatment Plants in the Dutch Food and Beverage Industry', Environmental and Resource Economics 12, 113-136.

Kemp, R. and L. Soete (1990), 'Inside the "Green Box": on the Economics of Technological Change and the Environment', in Freeman, C. and L. Soete, eds., New Explorations in the Economics of Technological Change. London: Pinter.

Keohane, N. O. (1999), 'Policy Instruments and the Diffusion of Pollution Abatement Technology', mimeo, Harvard University.

Keohane, N. O. (2001), 'Essays in the Economics of Environmental Policy', unpublished Ph.D. dissertation, Harvard University. 
Kerr, S. and R. G. Newell (2000), 'Policy-Induced Technology Adoption: Evidence from the U.S. Lead Phasedown', Resources for the Future Discussion Paper 01-14, (Resources for the Future, Washington, DC).

Kneese, A. and C. Schultze (1975), Pollution, Prices, and Public Policy. Washington, D.C.: Brookings Institution.

Kolstad, C. D. and M. H. L. Turnovsky (1998), 'Cost Functions and Nonlinear Prices: Estimating a Technology with Quality-Differentiated Inputs', Review of Economics \& Statistics 80, 444-453.

Laffont, J. and J. Tirole (1996), 'Pollution Permits and Compliance Strategies', Journal of Public Economics 62, 85-125.

Landjouw, J. O. and A. Mody (1996), 'Innovation and the International Diffusion of Environmentally Responsive Technology', Research Policy 25, 549-571.

Levin, S., S. Levin and J. Meisel (1987), 'A Dynamic Analysis of the Adoption of a New Technology: The Case of Optical Scanners', Review of Economics and Statistics 69, 12-17.

Magat, W. A. (1978), 'Pollution Control and Technological Advance: A Dynamic Model of the Firm', Journal of Environmental Economics and Management 5, 1-25.

Magat, W. A. (1979), 'The Effects of Environmental Regulation on Innovation', Law and Contemporary Problems 43, 3-25.

Maloney, M. T. and G. L. Brady (1988), 'Capital Turnover and Marketable Pollution Rights', Journal of Law and Economics 31, 203-226.

Malueg, D. A. (1989), 'Emission Credit Trading and the Incentive to Adopt New Pollution Abatement Technology', Journal of Environmental Economics and Management 16, 52-57.

Mansfield, E. (1968), Industrial Research and Technological Innovation. New York: Norton.

Mansfield, E. (1989), 'Industrial robots in Japan and the USA', Research Policy 18, 183-192.

Marin, A. (1991), 'Firm Incentives to Promote Technological Change in Pollution Control: Comment', Journal of Environmental Economics and Management 21, 297-300.

Martin, S. and J. Scott (2000), 'The Nature of Innovation Market Failure and the Design of Public Support for Private Innovation', Research Policy 29, 437-448.

McCubbins, M. D., R. G. Noll and B. R. Weingast (1989), 'Structure and Process, Politics and Policy: Administrative Arrangements and the Political Control of Agencies', Virginia Law Review 75, 431-482.

Metcalf, G. E. and K. A. Hassett (1999), 'Measuring the Energy Savings from Home Improvement Investments: Evidence from Monthly Billing Data', The Review of Economics and Statistics 81, $516-528$.

Milliman, S. R. and R. Prince (1989), 'Firm Incentives to Promote Technological Change in Pollution Control', Journal of Environmental Economics and Management 17, 247-265.

Milliman, S. R. and R. Prince (1992), 'Firm Incentives to Promote Technological Change in Pollution Control: Reply', Journal of Environmental Economics and Management 22, 292-296.

Montero, J. P. (2000), 'Market Structure and Environmental Innovation', mimeo Catholic University of Chile.

National Science Board (1998), Science and Engineering Indicators - 1998. Washington: National Science Foundation, available online at http://www.nsf.gov/sbe/srs/seind98/frames.htm

Nelson, R. and S. Winter (1982), An Evolutionary Theory of Economic Change Cambridge, MA: The Belknap Press of Harvard University Press.

Nelson, R., T. Tietenberg and M. Donihue (1993), 'Differential Environmental Regulation: Effects on Electric Utility Capital Turnover and Emissions', Review of Economics and Statistics 75, 368-373.

Newell, R. G., A. B. Jaffe and R. N. Stavins (1999), 'The Induced Innovation Hypothesis and EnergySaving Technological Change', The Quarterly Journal of Economics 114, 941-975.

Nordhaus, W. D. (2000), 'Modeling Induced Innovation in Climate-Change Policy', mimeo, Yale University. 
Oates, W. E., K. Palmer and P. R. Portney (1993), 'Environmental Regulation and International Competitiveness: Thinking About the Porter Hypothesis', Resources for the Future Discussion Paper 94-02, Resources for the Future, Washington, D.C.

Ohta, M. and Z. Griliches (1976), 'Automobile prices revisited: Extensions of the hedonic hypothesis', in N.E. Terleckyj, ed., Household Production and Consumption. New York: National Bureau of Economic Research.

Ohta, M. and Z. Griliches (1986), 'Automobile Prices and Quality: Did the Gasoline Price Increases Change Consumer Tastes in the U.S.?', Journal of Business \& Economic Statistics 4, 187-198.

Organization for Economic Cooperation and Development (2000), Basic Science and Technology Statistics: 1999 Edition. Paris: Organization for Economic Cooperation and Development.

Orr, L. (1976), 'Incentive for Innovation as the Basis for Effluent Charge Strategy', American Economic Review 66, 441-447.

Oster, S. (1982), 'The Diffusion of Innovation Among Steel Firms: The Basic Oxygen Furnace', The Bell Journal of Economics 13, 45-56.

Pakes, A., S. Berry and J. A. Levinsohn (1993), 'Applications and Limitations of Some Recent Advances in Empirical Industrial Organization: Prices Indexes and the Analysis of Environmental Change', American Economic Review 83, 240-246.

Palmer, K., W. E. Oates and P. R. Portney (1995), 'Tightening Environmental Standards: The BenefitCost or the No-Cost Paradigm?' Journal of Economic Perspectives 9, 119-132.

Parry, I. W. H. (1998), 'Pollution Regulation and the Efficiency Gains from Technological Innovation', Journal of Regulatory Economics 14, 229-254.

Pindyck, R. (1991), 'Irreversibility, Uncertainty, and Investment', Journal of Economic Literature 29, 1110-1152.

Pizer, W. A., W. Harrington, R. J. Kopp, R. D. Morgenstern and J. Shih (2001), 'Technology Adoption and Aggregate Energy Efficiency', Resources for the Future Discussion Paper 01-21. Resources for the Future, Washington, DC.

Popp, D. (2001a), 'Induced Innovation and Energy Prices', American Economic Review, forthcoming.

Popp, D. (2001b), 'The Effect of New Technology on Energy Consumption', Resource and Energy Economics 23(4), 215-239.

Porter, M. E. and C. van der Linde (1995), 'Toward a New Conception of the EnvironmentCompetitiveness Relationship', Journal of Economic Perspectives 9, 97-118.

Purvis, A. and J. Outlaw (1995), 'What We Know About Technological Innovation to Achieve Environmental Compliance: Policy Issues for an Industrializing Animal Agriculture Sector', American Journal of Agricultural Economics 77, 1237-1243.

Reinganum, J. (1989), 'The Timing of Innovation: Research, Development and Diffusion', in R. Schmalensee and R. Willig, eds., Handbook of Industrial Organization, vol. 1. Amsterdam: North-Holland, pp. 850-908.

Reinhardt, F. L. (2000), Down to Earth: Applying Business Principles to Environmental Management. Boston: Harvard Business School Press.

Reppelin-Hill, V. (1999), 'Trade and Environment: An Empirical Analysis of the Technology Effect in the Steel Industry', Journal of Environmental Economics and Management 38, 283-301.

Requate, T. (1998), 'Incentives to Innovate under Emission Taxes and Tradeable Permits', European Journal of Political Economy 14, 139-165.

Romer, P. M. (1994), 'The Origins of Endogenous Growth', Journal of Economic Perspectives 8, 3-22.

Rose, N. and P. Joskow (1990), 'The Diffusion of New Technologies: Evidence from the Electric Utility Industry', Rand Journal of Economics 21, 354-373.

Ross, M. (1990), 'Capital Budgeting Practices of Twelve Large Manufacturers', in P. Cooley, ed., Advances in Business Financial Management. Chicago: Dryden Press, pp. 157-170. 
Ruderman, H., M. D. Levine and J. E. McMahon (1987), 'The Behavior of the Market for Energy Efficiency in Residential Appliances Including Heating and Cooling Equipment', The Energy Journal 8, 101-123.

Sanstad, A., C. Blumstein and S. Stoft (1995), 'How High are Option Values in Energy-efficiency Investments', Energy Policy 23, 739-743.

Scherer, F. (1986), Innovation and Growth, Schumpeterian Perspectives. Cambridge, MA: The MIT Press.

Scherer, F. M. and D. Harhoff (2000), 'Technology Policy for a World of Skew-Distributed Outcomes', Research Policy 29, 559-566.

Scherer, F., D. Harhoff and J. Kukies (2000), 'Uncertainty and the Size Distribution of Rewards from Technological Innovation', Journal of Evolutionary Economics 10, 175-200.

Schmalensee, R. (1994), 'The Costs of Environmental Protection', in M.B. Kotowski, ed., Balancing Economic Growth and Environmental Goals. Washington, D.C.: American Council for Capital Formation, Center for Policy Research, pp. 55-75.

Schumpeter, J. (1942), Capitalism, Socialism and Democracy. New York: Harper.

Shama, A. (1983), 'Energy Conservation in U.S. Buildings, Solving the High Potential/Low Adoption Paradox from a Behavioral Perspective', Energy Policy 11, 148-168.

Shrestha, R. M. and B. K. Karmacharya (1998), 'Testing of Barriers to the Adoption of EnergyEfficient Lamps in Nepal', The Journal of Energy and Development 23(1), 71-82.

Simon, H. A. (1947), Administrative Behavior: A Study of Decision-making Processes in Administrative Organization. New York: Macmillan Company.

Spence, A. M. (1984), 'Cost Reduction, Competition and Industry Performance', Econometrica 52(1), 101-121.

Stavins, R. N. (2001), 'Experience with Market-Based Environmental Policy Instruments', in K. Mäler and J. Vincent, eds., Handbook of Environmental Economics. Amsterdam: Elsevier Science, forthcoming.

Stewart, R. B. (1981), 'Regulation, Innovation, and Administrative Law: A Conceptual Framework', California Law Review 69, 1256-1270.

Stoneman, P. (1983), The Economic Analysis of Technological Change. Oxford: Oxford University Press.

Sutton, J. (1998), Technology and Market Structure. Cambridge, MA: The MIT Press.

Tirole, J. (1988), The Theory of Industrial Organization. Cambridge, MA: The MIT Press.

Ulph, D. (1998), 'Environmental Policy and Technological Innovation', forthcoming in C. Carraro and D. Siniscalaco, eds., Frontiers of Environmental Economics Cheltenhsam: Edward Elgar.

Weitzman, M. L. (1974), 'Prices vs. Quantities', Review of Economic Studies 41, 477-491.

Wilcox, J. (1984), ‘Automobile Fuel Efficiency: Measurement and Explanation', Economic Inquiry 22, 375-385.

Winter, S. G., Y. M. Kaniovski and G. Dosi (2000), 'Modeling Industrial Dynamics with Innovative Entrants', Structural Change and Economic Dynamics 11, 255-293.

Zerbe, R. O. (1970), 'Theoretical Efficiency in Pollution Control', Western Economic Journal 8, 364-376. 